\title{
Telomeres and Reproductive Aging
}

\author{
Sena Aydos \\ Department of Medical Biology University of Ankara, \\ Faculty of Medicine, Ankara \\ Turkey
}

\section{Introduction}

Telomeres are special deoxyribonucleic acid (DNA) structures that "cap" the ends of eukaryote chromosomes. The term telomere derives from the Greek words telos, meaning "end", and meros meaning "part". The existence of these end-parts of chromosomes was first suggested in 1938 by Muller (Muller, 1938). Telomere length is involved in biological aging and disease processes. Telomere length is affected by several factors, such as aging, aging related diseases, gender, genetic and environmental factors. Telomere length, which is a highly variable and heritable trait (Jeanclos et al., 2000; Slagboom et al., 1994; Nawrot et al., 2004; Vasa-Nicotera et al., 2005; Andrew et al., 2006; Biscoff et al., 2005), is greater in women than men (Jeanclos et al., 2000, Nawrot et al., 2004; Vasa-Nicotera et al., 2005; Biscoff et al., 2005, Benetos et al., 2001; Mayer et al., 2006; Fitzpatrick et al., 2007). As well as genetic factors environmental factors are also influential on leukocyte telomere dynamics. Environmental factors, including smoking (Nawrot et al., 2004; Valdes et al., 2005), obesity (Fitzpatrick et al., 2007; Valdes et al., 2005; Gardner et al., 2005), psychological stress (Epel et al., 2005) and low socio-economic status (Cherkas et al., 2006) are associated with shortened leukocyte telomere length. Leukocyte telomere length can be determined relatively easily and the processing of leukocytes is rather simple. Leukocyte telomere length has been studied extensively in humans in relation to both the aging process and several pathologies. There are many correlative studies demonstrating a link between telomere length and aging (Slagboom et al, 1994, Wu et al, 2003).

Aging has been defined as a normal biological process, which involves the cumulative deposition of damaged and defective cellular components, loss of cell or organ physiological functions and inability to perform physical activity. Cellular senescence and aging have been reported to be related to shortening telomere length (Aubert \& Lansdorp, 2008). Multiple surveys conducted in human populations have demonstrated the shortening of telomere length in various tissues during the aging process. Many theories have been proposed for aging, yet still, no single theory is able to account for all the different views. Among the most widely accepted theories on aging are the Hayflic limit theory and telomere theory (Gavrilov \& Gavrilova, 2003). Shortened leukocyte telomere length is observed in individuals with aging-related diseases, including hypertension (Jeanclos et al., 2000; Benetos et al., 2001), insulin resistance (Gardner et al., 2005; Demissie et al., 2006; Aviv et al., 2006), atherosclerosis (Brouilette et al., 2003; Benetos et al., 2004), myocardial infarction (Brouilette et al., 2003, 2007; Cawthon et al., 2003), stroke (Fitzpatrick et al., 2007) and 
dementia (von Zglinicki et al., 2000; Panossian et al., 2003). Furthermore, it is suggested that the relationship between leukocyte telomere length and some of these variables could be modified by the aging process itself (Aviv et al., 2006). Unlike other systems, first signs of reproductive aging begin at mid 30 in normal condition. Telomere may be one of the responsible factors in also reproductive aging especially in women.

\section{Telomere biology}

The nucleoprotein complexes, referred to as telomeres, are specialized structures located at both ends of linear eukaryote chromosomes. Human telomeres are composed of a short repetitive DNA sequence (TTAGGG) and bound by a six-protein complex known as shelterin. TTAGGG repeat-binding factors (TRF ) 1 and 2, bind to the TTAGGG sequences in double-stranded DNA, and one subunit, proteins for the protection of telomeres (POT1), bind to these sequences in single stranded form (de Lange, 2005; Pan et al., 2011). They are linked by three additional shelterin proteins, TIN2, TPP1, and Rap1, composing a complex called shelterin that enables cells to distinguish telomeres from sites of DNA damage (Fig.1). Three shelterin subunits, TRF1, TRF2, and POT1 directly recognize TTAGGG repeats. TRF1 and TIN2 regulate telomere length, TRF2 prevents end to end fusion and activation of DNA damage response. It has been reported that, additional proteins capable of interacting with telomeric proteins which are involved in DNA damage response and double-strand break repair also have implications for telomere length regulation and chromosome end protection (De Boeck et al., 2009; Gilson and Geli, 2007; Palm and de Lange, 2008).

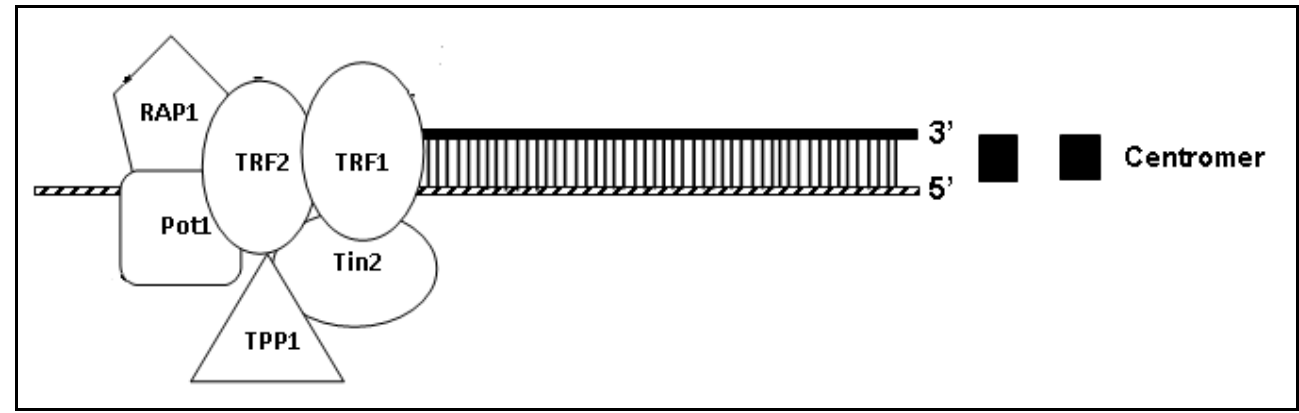

Fig. 1. Schematic representation of chromosome termini. In mammals telomeric sequences are enclosed by a complex which is composed of 6 different proteins (TRF1, TRF2, POT1, TIN2, TPP1 AND RAP1) that have specificity for either the single or double stranded DNA, called shelterin.

Telomeres act as the cap of the chromosome and maintain genomic integrity by preventing end-to-end fusions. (Murnane \& Sabatier, 2004). Telomeres shorten with age through at least two mechanisms: (1) replicative senescence in dividing cells (2) and a damage response to reactive oxygen in non-dividing cells (Passos \& von Zglinicki, 2005).

The shortening of telomeres occurs in each round of cell division consequential to the inability of conventional DNA polymerases to replicate the ends of linear chromosomes, in other words, as a result of the so-called 'end replication problem'. DNA replication involves 
the simultaneous copying of antiparallel DNA strands, such that replication proceeds in opposite directions, along a "leading" strand and a "lagging" strand. Daughter strand DNA synthesis takes place progressively on the leading template in the $5^{\prime}$ to $3^{\prime}$ direction, whilst on the lagging strand template, although seemingly backward in the form of Okazaki fragments, DNA synthesis also proceeds in the $5^{\prime}$ to $3^{\prime}$ direction. The leading daughter strand is almost completely synthesized, by the time the DNA polymerase reaches the $5^{\prime}$ end of the leading template. However, a primer is required to start replication. If the RNA primer occupying the $5^{\prime}$ end of the daughter strand is removed, it is not possible for the overlapping single strand to be replicated. The localization of this primer is the beginning of the leading strand and the end of the lagging strand. Consequently, the 5 ' end of each of the antiparallel daughter strands becomes one primer-length shorter. Chromosomes grow shorter with each consecutive replication (Fig 2).

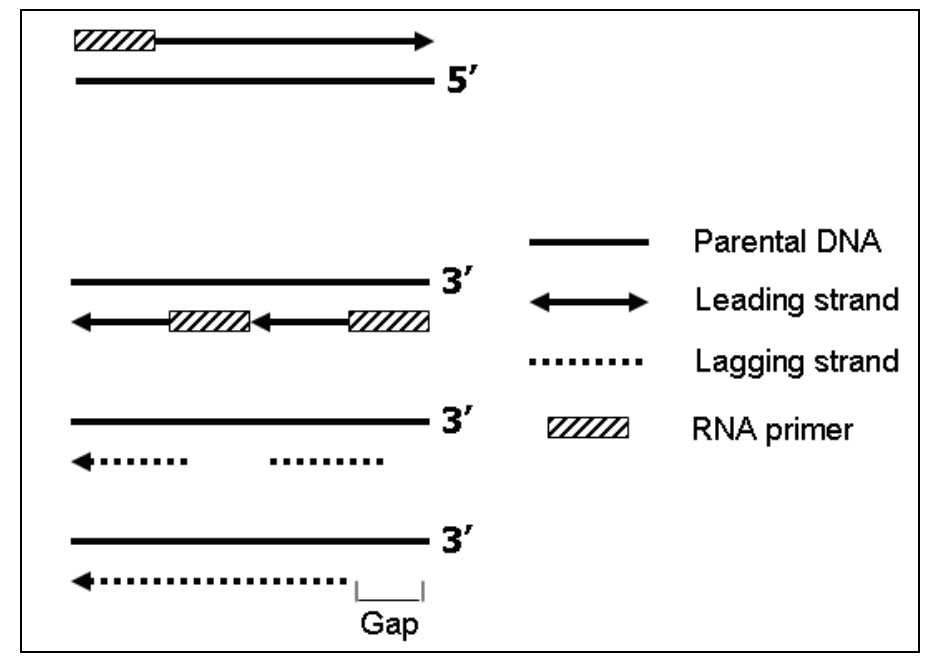

Fig. 2. In a linear chromosome, the leading strand can be synthesized by DNA polymerase until the end of the chromosome. On the other hand, in the lagging strand, synthesis by DNA polymerase is based on a series of fragments, referred to as Okazaki fragments, each of which requires an RNA primer. When the RNA primer occupying the 5 ' end of the daughter strand is removed, it is not possible for the overlapping single strand to be replicated. The localization of this primer is the beginning of the leading strand and the end of the lagging strand. Consequently, the 5 ' end of each of the antiparallel daughter strands becomes one primer-length shorter. Chromosomes grow shorter with each consecutive replication.

Due to the end replication problem, it is estimated that, in most human cells, a loss of less than 10 base pairs occurs per division. In fact, most often, the rate of loss is much higher, calculated as 50-200 base pairs per division in humans (Takai et al., 2003). The underlying reason of this difference has aroused great interest, but remains poorly understood (Lansdorp, 2005). Oxidative stress is thought to be one of the main factors involved (Houben et al., 2008). Exonuclease activity degrading the $5^{\prime}$ end is another major factor. The 
degradation of the primer on the lagging strand and the action of a putative $5^{\prime}$ to $3^{\prime}$ exonuclease lead to shortening of the $5^{\prime}$ end of the telomere and the formation of a $3^{\prime}$-end overhang structure (Wai, 2004). Both, the nuclease-dependent resection of telomeres create single-stranded G-rich-strand overhangs and the inability of DNA polymerase to copy through the ends in lagging-strand during DNA replication cause to loss of telomeric repeats in each replication (Shay \& Wright, 2000). Telomeric DNA is much more susceptible to oxidative damage than nontelomeric DNA, at least partly due to its high guanine content. While most studies investigating the effects of oxidative stress on telomere loss have been conducted in vitro (Richter \& von Zglinicki, 2007), correlative and experimental studies have begun to demonstrate the link between oxidative stress and the rate of telomere loss in vivo (Houben et al., 2008; Cattan et al., 2008). Telomeres shorten throughout the lifespan of human cells. When telomeres shorten to a critical length, the cell ceases mitotic division, thus, replicative senescence occurs. This phenomenon, which is referred to as the Hayflick limit (Hayflick \& Moorhead, 1961), demonstrates that telomere length acts as a major determinant of replicative capacity. Therefore, it is indicated that, telomere length, in a way, serves as a mitotic clock and constitutes a marker of biological aging, representative of the aging process other than chronological aging (the measure of time elapsed since a person' birth). In his research dating back to 1961, Hayflick showed that a cell culture population of normal human fetal cells divided between 40 and 60 times. Accordingly, he suggested that cells were capable of undergoing only a limited number of cell divisions before entering a senescence phase (Hayflick \& Moorhead, 1961). Because of limited telomerase activity in normal somatic cells, it is presumed that, at the Hayflick limit (Ml), one or more telomeres lose TTAGGG beyond a crtical threshold activating a checkpoint mechanism that arrest cell growth. If partially transformed cells that skip this checkpoint without telomerase being activated, they continuously lose telomeres until "crisis" (M2). Cells capable of activating telomerase, most probably by mutation, as seen in most of cancer cells could survive the crisis. Only then can telomeres be maintained at stable length (Fig 3).

Senescent cells may produce protein aggregates different than those pertaining to quiescent but non-senescent adjacent cells. The homeostasis of tissues characterized by the senescence of cells, which emerges and is recognized as aging, could be changed (Shay \& Wright, 2007). The shortening of telomeres is encountered in rapidly proliferating cells of the skin, gastrointestinal system and blood.

An oxidation-trigerred DNA damage response that excises the oxidized sequence leads to telomere attrition also exist in non-dividing cells (Passos \& von Zglinicki, 2005). ROSinduced telomere shortening may result from direct injury to guanine repeat telomere DNA by ROS. A large number of independent studies have shown that (von Zglinicki, 2002; Serra et al., 2003) telomere shortening increased significantly under mild oxidative stress, in comparison to that observed under normal conditions. In somatic cells, the rate of telomere shortening can be suppressed by the addition of an antioxidant. Furumoto et al showed that the telomere shortening rate slowed after enrichment with ascorbic acid, which is a strong antioxidant (Furumoto et al., 1998). In most cases, the contribution of oxidative damage to telomere loss is much greater than that of the end-replication problem alone. Telomeres, as triple-G-containing structures, are highly sensitive to damage by oxidative stress (Henle et 
al., 1999), alkylation (Petersen et al., 1998) or ultraviolet (UV) irradiation (Oikawa et al., 200)]. Thus, stresses of high intensity may lead to telomere shortening without DNA replication, as a result of the induction of telomeric double-strand breaks at high frequency (Bar-Or et al., 2001; Oikawa et al., 2001).

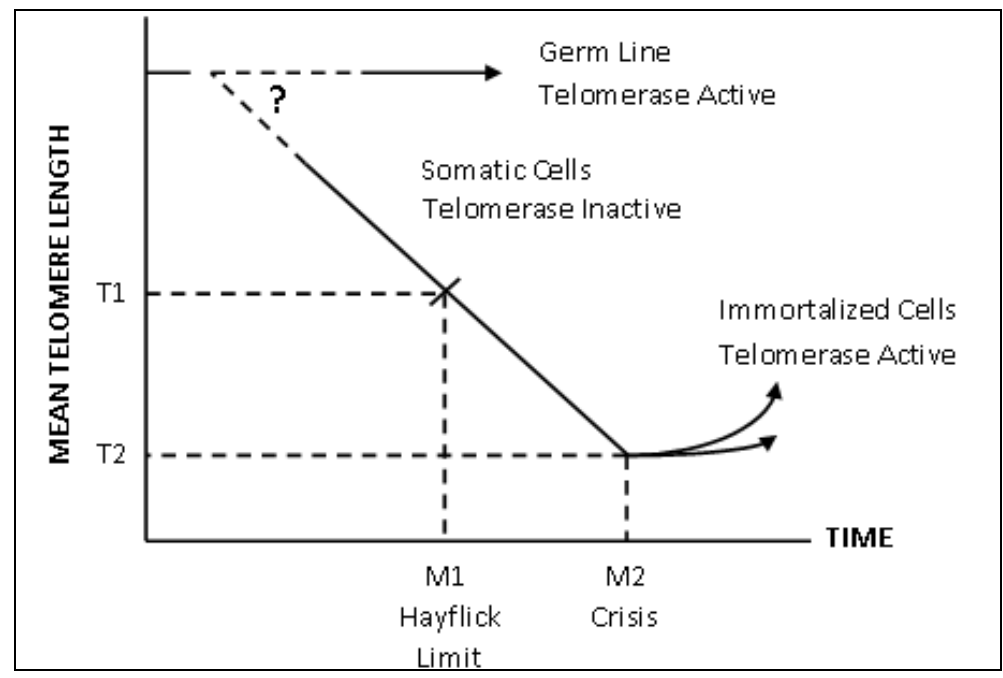

Fig. 3. Schematic representation of the telomere hypothesis of cell aging and

immortalization. Alterations observed in telomere length over time (in cell divisions) are shown for germ line, normal somatic and transformed cells. Events in the early embryonic stage, at the beginning of the time axis, remain unknown (dotted lines). As telomere length is maintained in germ-line cells, it is thought that telomerase is activated at some point in gametogenesis, yet it is unclear whether telomerase activity is present in the early embryo prior to germ-line development. On the contrary, the decrease observed in telomere length and the lack of telomerase activity in normal somatic cells, suggest that telomerase is repressed in these cells. It is presumed that, at the Hayflick limit (Ml), one or more telomeres lose a threshold amount of TTAGGG, pointing out to a checkpoint in cell growth. The mean telomere length at this point is shown as T1. Partially transformed cells that skip this checkpoint without telomerase being activated, continuously lose telomeres until "crisis" (M2), at the point where most cells have critically short telomeres on many chromosomes (mean telomere length $=\mathrm{T} 2$ ). Cells capable of activating telomerase, most probably by mutation, could survive the crisis. Only then can telomeres be maintained at stable length.

The telomere end replication problem is solved by the use of a cellular enzyme called telomerase. Telomerase is a ribonucleoprotein complex composed of a catalytic subunit of component telomerase reverse transcriptase (TERT) responsible for the synthesis of new telomeric DNA repeats, and a telomerase RNA component (TERC) that functions as a template (Aubert \& Lansdorp, 2008). This enzyme is capable of compensating for progressive telomere attrition through the de novo addition of TTAGGG repeats to chromosome ends (Greider \& Blackburn, 1985) as well as of preventing telomere shortening 
in some cells, including male germ, stem and cancer cells (Keefe \& Liu, 2009). The accelerated aging phenotype occurs in both TERC and TERT gene knockout mice (Greer \& Brunet, 2008). As well as various pathologies, telomere dysfunction in late generations also leads to decline in fertility in female mice, eventually resulting in sterility (Lee et al., 1998; Herrera et al., 1999). Recent studies have revealed that telomerase function is regulated by an epigenetic mechanism involving histone methylation and deacetylation as well as CpG methylation. Strikingly extended telomeres were detected in mouse embryonic stem cells with deficient DNA methyltransferase (DNMT)1, or both DNMT3a and DNMT3b (Gonzalo et al., 2006). Increased telomere length is observed in histone methyltransferase-deficient MEFs. Elimination of acetylated histone H4 lysine 12 (H4K12) at telomeric heterochromatin resulted in reduction of telomere replication and recombination (Zhou et al., 2011).

Meiocytes may display telomerase independent mechanisms for telomere elongation that are based on homologous recombination between telomeres of different chromosomes. In other words, these cells may present with an alternative pathway for the lengthening of telomeres (ALT) (Chin et al., 1999). A high degree of heterogeneity of telomeres, including among others elongated and shortened telomeres, is generated by the ALT pathway in somatic cells with ALT activity (Nittis et al., 2008). However, to date, the presence of this mechanism in germ cells has not been proven.

Leukocyte telomere length varies greatly among individuals and shortens with aging. Significant variations are observed, in particular, during the first few years of life (Rufer et al., 1999). Telomere length remains relatively stable throughout childhood, preadolescence and adolescence. Eventually, telomere length attrition reaches its peak at very old age, beyond 100 .

\section{Reproductive aging}

\subsection{In males}

Spermatogenesis and male reproductive functions gradually decline with aging. Semen quality and pregnancy outcomes appear to decline. Dunson et al showed that semen parameters begin to decline after 35 years of age. As a result, male fertility also decreases substantially in the late 30 s and continues to decrease after the age of 40 (Dunson et al., 2004).

In a study on couples undergoing intracytoplasmic sperm injection (ICSI), it was found that increased age in men with oligozoospermia resulted in decreased implantation and pregnancy rates. In these couples, pregnancy rates decreased $5 \%$ for each year of paternal age, however, this effect was not observed in normozoospermic men (Ferreira et al., 2010). Levels of ROS that bind to the DNA that may cause DNA fragmentation have been found to be significantly higher in seminal ejaculates of healthy fertile men older than 40 years. Protective antioxidant scavenging enzyme concentrations are low in spermatozoa, which may reduce the chances of pregnancy, as men become progressively less fertile with age (Desai et al., 2010; Cocuzza et al., 2008). Based on findings detected in infertile men, it has been shown that aging affects the chromatin integrity of spermatozoa (Vagnini et al., 2007; Plastira et al., 2007). Numerical (such as disomy of chromosome 3, higher incidence of extra group $\mathrm{C}$ chromosomes including $\mathrm{X}$ chromosome, and group $\mathrm{G}$ chromosome or by extra 
group D and F chromosome) (Sartorelli et al., 2001) and structural aberrations in sperm chromosome also increase with paternal age. When a female baby is born, mitotic divisions of primordial germ cells have already been completed and meiosis has been arrested at prophase I. Therefore, a female baby is born with all the eggs she will have throughout her life, whilst mitotic spermatogenesis is an ongoing process throughout most of the male's life. The number of germ-line divisions is much higher in males than females. Consequently, more replications enhance the chance for spontaneous germ-line mutations that arise during the mitotic phase of spermatogenesis (Crow, 2000; Glaser \& Jabs, 2004; Tarin et al. 1998; Kuhnert \& Nieschlag, 2004). Transmitted to their offspring by older fathers, these germline mutations might cause an increased rate of clinical disorders such as autism, schizophrenia, and autosomal dominant disorders including achrondroplasia, osteogenesis imperfecta, and Marfan syndrome. As well as numerical and structural aberrations in sperm chromosome, some clinical manifestations such as cryptorchidism, hypospadias, and testicular cancer also increase with paternal age (Stewart \& Kim, 2011). Fisch et al found that a paternal effect on the increased risk of Down syndrome was an important factor when both parents were over 35 , but not when the female partner was younger than 35 years of age. In this study, the incidence of Down syndrome seemed to be related to paternal age at an approximate rate of $50 \%$ when the male was older than 35 and the female was older than 40 (Fisch et al., 2003).

Two previous studies conducted in 125 (Unryn et al., 2005) and 2,433 (De Meyer et al., 2007) participants demonstrated that leukocyte telomere length in adult offspring and paternal age were positively correlated with each other. This could be explained by the presence of a subset of sperm with longer telomeres in older men. It is possible that numerous replications of the male germ-line that occur with advancing age exert a powerful selection pressure that produces stem cells resistant against the effects of aging (Wallenfang et al., 2006). Sperm with greater telomere length might emerge from a subset of germ-line stem cells less resistant to aging-related oxidative stress, either due to increased resistance to its action - or having undergone fewer replications before meiosis. Epigenetic processes that occur in germ-line stem cells with advancing age in men may result in the elongation of telomeres (Blasco, 2007). Through the inheritance of the particular genetic constitution of such sperm (with or without DNA mutations) across generations, some offspring with longer leukocyte telomere length would emerge.

Although available data stress the important impact of male aging on telomere status, further studies are needed to clarify such correlation.

\subsection{In females}

During the aging process, in addition to several physiological changes in other systems, age-related changes, including the decline of ovarian functions resulting from reductions in the quantity and quality of the oocyte/follicle pool, also occur. Two important changes are observed in human ovaries with aging: 1) decline in oocyte genomic stability leading to aneuploidy (Hassold \& Hunt, 2001) and 2) depletion of ovarian follicles (Faddy et al., 1992; Faddy, 2000).

Women display a marked increase in infertility, chromosomal nondisjunction associated miscarriage, and birth defects, as a result of reproductive aging characterized by a markedly 
increased duration of meiotic dysfunction. In women, fertility begins to decline starting from the mid-30s. Furthermore, as women grow older, the rate of miscarriage and/or aneuploid offspring increases dramatically. In clinically diagnosed pregnancies, trisomy incidence tends to be low (2-3\%) in women in their 20 's, yet rises to about $35 \%$ in women in their 40's (Hassold \& Hunt, 2001). Previously conducted studies on in vitro fertilization (IVF) have proven that female age constitutes the most significant factor influential on clinical outcome (Wright et al., 2006). Based on studies investigating the effects of aging on oocytes, it has been concluded that maternal age has negative effect on the expression of oocyte genes responsible for major cellular activities such as cell cycle regulation, energy pathways and mitochondrial functions, and oxidative stress (Hamatani et al., 2004, Steuerwald et al., 2007).

\subsubsection{Decline in oocyte genomic stability leading to aneuploidy}

Most human aneuploidies occurring in embryos originate from the egg and not sperm (May et al., 1990; Hassold et al., 1987, 1991; Takaesu et al., 1990; Martin \& Rademaker, 1987). Indirect proof suggests that, in addition to the reduction of oocyte quantity, impaired oocyte quality also contributes significantly to the age-related decline of fertility in women (Ottolenghi et al., 2004). As women age, their oocytes increasingly show abnormalities in chromosome segretion and spindle morphology. Keefe and co workers proposed a telomere theory of reproductive aging in women (Keefe et al., 2006). According to this theory, telomere dysfunction in oocytes is responsible for several reproductive changes including meiotic dysfunction, increased aneuploidy resulting in miscarriage, decreased fertility rate and birth defects. In older women, the prolonged exit of oocytes from the production line and their chronic exposure to reactive oxygen results in the shortening of telomeres. In return, the shortening of telomeres brings about a reduction in chiasmata, the presence of abnormal meiotic spindles in oocytes, as well as cell cycle arrest, apoptosis and cytogenetic abnormalities in resulting embryos (Keefe et al., 2006).

\subsubsection{Oocyte senescence}

In females, meiosis begins during fetal development, becomes arrested at prophase I before birth, and remains in this stage until prior to ovulation in adulthood, up to 50 years later in humans, by means of the synthesis of several RNAs and proteins. At that time, oocytes with a diameter of 15-20 $\mu \mathrm{m}$ develop to become fully grown oocytes of 70-150 $\mu \mathrm{m}$ (Bacharova, 1985). Based on observations in the mouse model, it has been suggested that aging impairs the accumulation of maternal RNAs either required for oocyte-specific processes and metabolism, or presumably stored for later use during early embryonic development prior to activation of the embryonic genome (Hamatani et al., 2004). The long interval between meiotic prophase I arrest in the fetus and each ovulation cycle in aged women increases the incidence of aneuploidy.

\subsection{Meiotic chromosome and telomere}

The aging oocyte is responsible for problems associated with maternal age (Sauer, 1998; Stolwijk et al., 1997). As they are involved in the tethering of chromosomes and the 
facilitation of their alignment, pairing and synapsis, as well as the formation of chiasmata during early meiosis, telomeres play a major role in meiotic reproduction (Scherthan et al., 1996; Scherthan, 2006; Roig et al., 2004; Bass et al., 1997). The mechanisms of meiotic telomere maintenance and dynamics, including attachment to the nuclear envelope, are only partially understood (Adelfalk et al., 2009). In the early stage of meiosis, in order to facilitate the homologue alignment required for the formation of chiasmata, telomeres aggregate around the nuclear envelope, forming 'bouquets' with a stalklike attachment to the nuclear envelope. This structure aids in the formation of the meiotic spindle and is therefore critical to chromosomal division. In oocytes, the main cause of telomere shortening is reactive oxygen species (Liu et al., 2002a), which increase with maternal aging. Experimental telomere shortening by several generations in the telomerase-null state (Liu et al., 2002b), or exposure to pharmacologically induced reactive oxygen in mice, results in impaired chiasmata and synapsis, and even abnormal spindles and chromosome misalignment (Liu et al, 2002b; Liu et al., 2004). Furthermore, females present with chromosome misalignment, lack of efficient metaphase checkpoint control during meiosis, progression from the MI stage to the MII stage (LeMaire-Adkins et al., 1997; Roeder, 1997). Structural abnormalities in the meiotic spindle, including asymmetry of the spindle poles and failure of chromosomes to align on the metaphase plate, are present in almost $80 \%$ of eggs aspirated from women over the age of 40 , compared to only $17 \%$ of eggs from younger controls (Keefe et al., 2007). The mechanisms underlying chromosome misalignment and disruption of meiotic spindles caused by telomere dysfunction are not well understood. In a study conducted by Wood et al, female Mlh 1 mutant mice, which lacked normal recombination, also exhibited abnormal spindle assembly (Woods et al., 1999), and this may have caused improper homologous chromosome pairing and recombination during early meiosis. But still there is no clear information on whether telomeres play a role in spindle organization and chromosome segregetion in meiosis (Liu et al., 2002a). Experimental studies in adult mice have demonstrated that checkpoints for meiotic chromosome behaviour during the metaphase-to-anaphase transition are more efficient in males compared to females (Hunt et al., 1995; Le-Maire Adkins et al., 1997)]. Making use of telomerase null mice, it was investigated whether telomerase deficiency and/or telomere shortening could influence meiotic progression. The meiotic resumption and division (maturation) of germinal vesicle oocytes from fourth-generation telomerase null mice and first-generation telomerase null mice, as well as wild-type controls were compared. Chromosome misalignment and disruption of meiotic spindles at the metaphase stage appeared frequently in oocytes from fourth-generation telomerase null mice with very short telomeres, while meiotic progression, chromosome behavior, and spindle morphology in first-generation telomerase null mouse oocytes were comparable to those of wild-type mouse oocytes (Liu et al., 2002b).

In mammalian oogenesis, the sister chromatid cohesion is mediated by the multi-subunit protein complex called cohesin, which is composed of the meiosis-specific subunits REC8, STAGE3, SMC1 $\beta$, and SMC3 (Garcia-Cruz et al., 2010; Prieto et al., 2004; Revenkova \& Jessberger, 2005). It has been proposed that chromosome missegregation and aneuploidy in aged oocytes could result from loss of sister chromatid cohesion (SCC) through slow deterioration of cohesin (Hassold \& Hunt, 2001; Hunt \& Hassold 2008; Hodges et al., 2005). The cohesin component SMC1 $\beta$ prevents oocyte telomere shortening in mice (Adelfalk et al., 2009). It was observed that, in the oocytes of aged senescence-accelerated mice (SAM), meiotic cohesin proteins including REC8 (recombinant 8), STAG3 (stromal antigen 3) and 
SMC1 $\beta$ that are located between sister chromatids were significantly reduced. In the study of Adelfalk et al., it was reported that, cohesion SMC1 $\beta$ which was reduced significantly in aging, is necessary to prevent telomere shortening, and SMC3, present in all known cohesion complexes, properly localizes to telomeres only if SMC1 $\beta$ is present (Adelfalk et al., 2009). Therefore it is one of the responsible factors, aging related telomere shortening in oocyte and meiotic-dysfunction in female. Furthermore, cohesion degradation was more pronounced in SAM compared to hybrid F1 mice with age, which may explain the vulnerability of SAM to aneuploidy. This ageing mouse model revealed that defective cohesin is associated with increased incidence of chromosome misalignment and precocious segregation (Liu \& Keefe, 2008). In a study conducted by Hodges et al, the aging of female SMC1 $\beta-/-$ mice was associated with a dramatic loss of chiasmata. In parallel with the aging of SMC1 $\beta-/-$ oocytes, the loss of sister chromatid cohesion in metaphase I oocytes increases significantly (Hodges et al., 2005). This supports the increasingly distal localization of chiasmata on metaphase chromosomes, indicative of the inability of chiasmata being prevented from moving and slipping off chromosomes without SMC1 $\beta$ mediated sister chromatid cohesion (SCC). The expression of SMC1 $\beta$ cohesin takes place during prophase I prior to the primordial follicle stage with an aim of ensuring SCC in mice with advancing age. Slow degradation of SMC1 $\beta$-mediated cohesion has a major role in age-dependent increase of aneuploidy (Revenkova et al, 2010). Telomeres shortened by several generations in the telomerase-null state (Liu et al., 2002b), or exposure to pharmacologically induced reactive oxygen in mice (Liu et al., 2003), produce similar abnormalities in meiotic spindles, with asymmetry and congression failure (Battaglia et al., 1996).

Oocytes contain a maternally transmitted pool of mitochondria throughout the reproductive process, including the initiation and progression of preimplantation embryo development. This pool may be involved in oocyte development, and may be required for the modulation of sperm-triggered calcium oscillations (Dumollard et al., 2007). Denham Harman was the first to hypothesize that the dysfunction of mitochondria, which constitute the main cellular site of ROS production, could be responsible for aging, due to progressive accumulation of oxidative damage (Harman, 1956, 1972). Though sufficient evidence is lacking to show a causal connection between mitochondrial DNA damage, ROS production, and aging, the free radical theory remains one of the best explanations for aging. Thouas and co workers (Thouas et al., 2005) studied the developmental ability of both young and aged oocytes, in the event of mitochondrial injury, with an aim to determine the impact of mitochondrial dysfunctions on oocyte alterations observed in aging females. The researchers ascertained a decline in blastocyst development in both groups with this trend being sudden in aged embryos. Therefore, they proposed that, due to their greater sensitivity to mitochondrial damage, aged oocytes should be protected against the potential damage of IVF procedures. Despite the possibility of being abrogated by the transfer of injured germinal vesicles (GV) into healthy ooplasts, compromised developmental potential as a result of induced mitochondrial damage in young oocytes at GV stage (Takeuchi et al., 2005) further supports the involvement of mitochondria in the reduced developmental potential of aged oocytes.

As confirmed by the observations referred to above, age-related ooplasmic dysfunction can be corrected by germinal vesicle transplantation, or micro-aspiration and transfer of ooplasm from younger eggs to older eggs. Preliminary studies suggest that novel IVF-based methods, including the transfer of mitochondria, have some clinical efficacy in rejuvenating 
fertility in older women (Malter \& Cohen., 2002). However, the development of these highly invasive methods in ART requires a better understanding of processes that involve mitochondrial DNA replication and transcription, since asynchrony between mitochondrial and nuclear genomes could lead to problems in mitochondrial function, localization, and biogenesis (Harvey et al., 2007). Oocyte aging being a result of oxidative stress, in other words, a consequence of accumulated damage caused by increased levels of reactive oxygen species (ROS), is the most widely accepted proposal related to reproductive aging (Harman 1956; Tarin, 1995). It has been demonstrated that the expression of genes, including oxidative stress genes, differs between aged and younger oocytes (Hamatani et al., 2004, Steuerwald et al., 2007). Oxidative stress genes downregulated in aged oocytes belong to the family of thioredoxins, which are ATP-binding proteins that act as antioxidants against oxidative stress-induced apoptosis. The hypothesis that aging is related to decreased antioxidant defenses is supported by findings in mice. It has been observed that mature oocytes from aged mice display decreased activity levels of glutathione (GSH) and GSHtransferase (Tarin et al., 2004), which are factors that play an important role in cellular defense against ROS. In addition to endogenous ROS, oocytes may also be damaged by those produced in the follicular microenvironment during their prolonged stay in the ovary and/or as a consequence of a compromised oxygen supply (van Blerkom, 2000). Available data on how ROS production and mitochondrial function contribute to replicative senescence remains limited (Passos \& von Zglinicki, 2005). Research has demonstrated that accelerated telomere shortening is observed under increased oxidative stress, and that this could be reversed by antioxidants (Xu et al., 2000, Bar-Or et al., 2001). Damage-induced telomere shortening cannot be attributed solely to the induction of double-strand breaks, yet, unrepaired nucleotide or base damage of telomeres increases the proportion of unreplicated ends. Furthermore, it has been confirmed by Honda and colleagues that telomere single-strand-break frequency and shortening rate are positively correlated with each other (Honda et al., 2001a, 2001b). It remains unclear how the existence of singlestrand breaks accelerates telomere shortening and why single-strand break repair is less efficient in telomeres compared to the interstitial noncoding regions of the genome (von Zglinicki, 2002). The prolonged interval between the birth of oocytes and ovulation (up to 45 years in some women) would also render oocytes susceptible to telomere independent replicating shortening, as guanine rich sequence and location in the nuclear membrane make telomeres susceptible to reactive oxygen species (ROS). Keefe and co workers suggested that telomeres provide a cytogenetic mechanism to explain the "two hits" of aging on the female reproductive system, one active during fetal life and the other during adult life (Keefe et al., 2006). Increased mitochondrial DNA (mtDNA) mutations from chronic exposure to ROS during the prolonged interval between the birth of oocytes and ovulation shorten telomeres in oocytes from older women. Short telomeres cause a reduced number of chiasmata, as well as abnormal meiotic spindles in oocytes, cell cycle arrest and apoptosis, and clinically, result in infertility, miscarriage, birth defects and cytogenetic abnormalities in embryos.

\subsubsection{Depletion of ovarian follicles}

Age-related changes in the human ovary involve not only oocyte aging with decline in oocyte genomic stability that leads to aneuploidy, but also the depletion of ovarian follicles (Faddy et al., 1992; Faddy, 2000; Hassold \& Hunt, 2001). During fetal life the ovaries have a 
stock of follicles, which should serve throughout the woman's reproductive lifespan. Besides the possible presence of germ stem cells in the postnatal ovary (Johnson et al., 2004; Liu et al., 2007), the number of follicles reduces exponentially, with a marked increase in the rate of disappearance from age 37-38 years onwards. When the supply drops below a thousand follicles, a number insufficient to sustain the cyclic hormonal process necessary for menstruation, menopause occurs at a mean age of 51 years (Faddy et al., 1992).

The timing of the menopause-related consequence of depletion of oocyte reserves, which occurs any time between 40-60 years of age (Kato et al., 1998; te Velde \& Pearson, 2002; Toner et al., 1991; Baker, 1963), displays a large amount of inter-individual variability. The risk of conceiving a trisomic pregnancy, similarly, displays inter-individual variability (Warburton et al., 2004; Nicolaides et al., 2005). This natural variation in reproductive aging may be the result of environmental and genetic factors that affect individual rates of cellular aging. Although several environmental factors have been proposed as risk factors for the early onset of menopause (Brambilla \& McKinlay 1989; Cramer et al., 1995; Kline et al., 2000; Pines et al., 2002), factors influencing the timing of menopause are not well understood (Snieder et al., 1998). Some genetic factors have recently been proposed to be determinants of the age at which menopause occurs. This idea is strongly supported by the following studies; the twin study which showed that the onset of menopause is genetically determined, yielding a heritability for age at menopause of 63\% (Whelan et al., 1990); the study on the correlation between the menopausal age of mother and daughter (Torgerson et al., 1997); and another study which ascertained family history as a predictor of early menopause (Cramer et al., 1995). Based on animal model research and epidemiological studies in human populations, it has been proposed that longevity is associated with prolonged reproductive lifespan. It has been reported that women living till a minimum age of 100 years are greater than four times more likely to have given birth while in their 40s, compared to women living to the age of 73 (Perls et al., 1997). Several alternative mechanisms have been proposed for the relationship between longevity and age at menopause: (i) positive effect of prolonged estrogen exposure in association with later menopause on life expectancy (Perls et al., 1997), (ii) direct effect of effective ovarian age on longevity (Hsin \& Kenyon, 1999; Cargill et al., 2003) or (iii) positive selection for women with slower rates of cellular aging by the use of selective pressures for maximizing female reproductive years by slow reproductive aging (Perls \& Fretts, 2001; Perls et al., 2002). As their length declines with each cell division, telomeres are accepted as a marker for cellular aging. Telomere length varies among individuals (Hastie et al., 1990) and it is suggested that it may have a role in the variability observed in reproductive aging. The variability of telomere length may arise from differences in telomere length at conception, telomerase activity during early development, rate of cell division and rate of telomere loss per cell division.

Telomeres shorten by at least two mechanisms, including replicative senescence and response to damage from reactive oxygen (Passos \& von Zglinicki 2005). As oocytes do not divide in adults, replicative senescence does not seem agreeable for them. However, female primordial germ cells divide during fetal life before entering meiosis. Inter-individual variations of telomere length in primordial germ cells may result from different sizes of follicular pools, and shorter telomeres may limit mitotic capacity during fetal development, reducing the size of the follicular pool (Keefe et al., 2006, Aydos et al., 2005). Previous 
studies have shown that telomere length is a strong predictor of the developmental potential of sister oocytes from women undergoing in vitro fertilization procedures (Keefe et al., 2007) and is also correlated with reproductive lifespan in women (Aydos et al., 2005). Research conducted by Keefe and co workers on sister eggs, aspirated during clinical in vitro fertilization procedures, demonstrated that, compared to patient age and other clinical parameters, telomere length is a more reliable indicator of pregnancy outcome following in vitro fertilization procedures, even in cases where telomere length is measured in only spare eggs. It was determined that, telomere length in chromosomes from spare eggs was strongly correlated with that in their associated first polar bodies $(\mathrm{R} 2=0.98)$. Therefore, it was considered that the telomere length of the actual embryo transferred could be estimated with greater accuracy in the future, compared to estimations based on the measurement of telomere length in a spare, sister oocyte (Keefe et al, 2004). Data obtained in a study carried out by Aydos et al revealed that telomere lengths of women at the same age were correlated with their reproductive life span. Dorland et al. (Dorland et al., 1998) studied general aging, ovarian aging and telomere length. In this study, women older than 34 years of age, who presented with unexplained infertility and had less than five oocytes following an induced cycle, were investigated. The women's reproductive lifes were accepted to cease soon. The researchers expected that if there was a relation between general aging and ovarian aging, women who were accepted to have aged ovaries would have shorter telomeres than the fertile women included in the control group. The contradictory results obtained were surprising. These results showed that, in the case of infertile women, cell divisions in all cells were less than that observed in the control (fertile) group. This was attributed to growth hormone deficiency. This study also showed that reproductive life span and telomere length were correlated with each other. Results were interpreted such that, in the presence of factors with negative impact on reproductivity and cell division, the mitotic capacity of cells would decrease. Accordingly, cells, in general, including leukocytes and primordial germ cells, divided less, and thus less primordial follicles were formed. For this reason, these women had less ovarian follicles, aged ovaries and also long leukocyte telomeres. Increased telomere length in premature ovarian failure (POF) reported in the study of Hanna et al, similar to the study conducted by Dorland et al, was explained by longer telomeres in blood, reflecting fewer mitotic divisions in the initial germ cell pool, which could also explain a smaller follicular pool and early menopause in POF patients (Hanna et al., 2009).

\section{Conclusion}

Aging, a normal biological process, which involves the cumulative deposition of damaged and defective cellular components, loss of cell or organ physiological functions and inability to perform physical activity also includes telomere shortening. Although aging affects female reproductive function more evidently then male, declining in fertility and conception rate, meiotic dysfunction, birth defects, increase failure rate of implantation, fertilization and resulting unsuccess outcome of pregnancy that are performed assisted reproduction techniques are seen both in men and women as a result of reproductive aging. In men spermatogenesis and reproductive functions gradually decline with aging. It was shown that semen parameters begin to decline after 35 years of age. Numerical and structural aberrations, DNA fragmentation in sperm chromosome also increases with paternal age (Vagnini et al., 2007; Plastira et al., 2007; Dunson et al., 2004). As a result, male fertility also 
decreases substantially in the late 30s and continues to decrease after the age of 40 (Dunson et al., 2004). Though telomere theory of reproductive aging proposed by Keefe and co workwers does not explain the aging of reproductive function in male, as telomere length is maintained by telomerase activity and telomere attrition of germ cells is not evident in men, this theory is appropriate for female reproductive aging. According to this theory, telomere dysfunction in oocytes is responsible for several reproductive changes including meiotic dysfunction, increased aneuploidy resulting in miscarriage, decreased fertility rate and birth defects. In older women, the prolonged exit of oocytes from the production line and their chronic exposure to reactive oxygen results in the shortening of telomeres. In return, the shortening of telomeres brings about a reduction in chiasmata, the presence of abnormal meiotic spindles in oocytes, as well as cell cycle arrest, apoptosis and cytogenetic abnormalities in resulting embryos (Keefe et al., 2006). Age-related changes in the human ovary involve not only oocyte aging with decline in oocyte genomic stability that leads to aneuploidy, but also the depletion of ovarian follicles (Faddy et al., 1992; Faddy, 2000; Hassold \& Hunt, 2001). During fetal life the ovaries have a stock of follicles, which should serve throughout the woman's reproductive lifespan. Besides the possible presence of germ stem cells in the postnatal ovary (Johnson et al., 2004; Liu et al., 2007), the number of follicles reduces exponentially, with a marked increase in the rate of disappearance from age 37-38 years onwards. When the supply drops below a thousand follicles, a number insufficient to sustain the cyclic hormonal process necessary for menstruation, menopause occurs at a mean age of 51 years (Faddy et al., 1992). The timing of the menopause-related consequence of depletion of oocyte reserves, which occurs any time between 40-60 years of age (Kato et al., 1998; te Velde \& Pearson, 2002; Toner et al., 1991; Baker, 1963), displays a large amount of inter-individual variability. This may be also explained by telomere length. Female primordial germ cells divide during fetal life before entering meiosis. Inter-individual variations of telomere length in primordial germ cells may result from different sizes of follicular pools, and shorter telomeres may limit mitotic capacity during fetal development, reducing the size of the follicular pool (Keefe et al, 2006, Aydos et al 2003). Previous studies have shown that telomere length is a strong predictor of the developmental potential of sister oocytes from women undergoing in vitro fertilization procedures (Keefe et al., 2007) and is also correlated with reproductive lifespan in women (Aydos et al., 2005). Therefore, telomeres most likely play a crucial role in female reproductive aging. However, the molecular mechanisms of telomere regulation in early and late meiosis need to be clarified not only for a better understanding of normal development but also of human diseases associated with female reproductive aging as well.

\section{References}

Adelfalk, C.; Janschek, J.; Revenkova, E.; Blei, C.; Liebe, B.; Gob, E.; Alsheimer, M.; Benavente, R., de Boer, E.; Novak, I.; Hoog, C.; Scherthan, H. \& Jessberger, R. (2009). Cohesin SMC1beta protects telomeres in meiocytes. J Cell Biol, Vol.187, No.2, (October 2009), pp.185-199, ISSN 0021-9525

Andrew, T.; Aviv, A.; Falchi, M.; Surdulescu, G.L.; Gardner, J.P.; Lu, X.; Kimura, M.; Kato, B.S.; Valdes, A.M. \& Spector, T.D. (2006). Mapping genetic loci that determine leukocyte telomere length in a large sample of unselected, female sibling pairs. Am J Hum Genet, Vol.78, No.3, (March 2006), pp.480-486, ISSN 0002-9297 
Aubert, G. \& Lansdorp, P. M. (2008). Telomeres and aging. Physiol Rev, Vol.88, No.2, (April 2008), pp.557-579, ISSN 0031- 9333

Aviv, A.; Valdes, A.M. \& Spector, T.D. (2006). Human telomere biology: pitfalls of moving from the laboratory to epidemiology. Int J Epidemiol, Vol.35, No.6, (December 2006), pp.1424-1429, ISSN 0300-5771

Aydos, S.E.; Elhan, A.H. \& Tukun, A. (2005). Is telomere length one of the determinants of reproductive life span? Arch Gynecol Obstet, vol.272, No.2, (July 2005), pp. 113-116, ISSN 09320067. ISBN 09320067

Aviv, A.; Valdes, A.; Gardner, J.P.; Swaminathan, R.; Kimura, M. \& Spector, T.D. (2006). Menopause modifies the association of leukocyte telomere length with insulin resistance and inflammation. J Clin Endocrinol Metab, Vol.91, No.2, (February 2006), pp.635-640, ISSN 0021-972X

Bacharova, R. (1985). Gene expression during oogenesis and oocyte development in mammals. Dev Biol, Vol.1, pp.453-524

Baker, T.G. A quantitative and cytological study of germ cells in human ovaries. Proc $R$ Soc Lond B Biol Sci, Vol.158, (October 1963), pp.417-433, ISSN 0080-4649

Bar-Or, D.; Thomas, G.W.; Rael, L.T.; Lau, E.P. \& Winkler, J.V. (2001). Asp-Ala-His-Lys (DAHK) inhibits copper-induced oxidative DNA double strand breaks and telomere shortening. Biochem. Biophys Res Commun, Vol.282, No.1, (March 2001), pp.356-360, ISSN 0006-291X

Bass, H.W.; Marshall, W.F.; Sedat, J.W.; Agard, D.A. \& Cande, W.Z. (1997) Telomeres cluster de novo before the initiation of synapsis: a three-dimensional spatial analysis of telomere positions before and during meiotic prophase. J. Cell Biol, Vol.137, No.1, (April 1997), pp.5-18, ISSN 0021-9525

Battaglia, D.E.; Goodwin, P.; Klein, N.A. \& Soules, M.R. (1996). Influence of maternal age on meiotic spindle assembly in oocytes from naturally cycling women. Hum Reprod, Vol.11, No.10, (October 1996), pp.2217-2222, ISSN 0268-1161

Benetos, A.; Okuda, K.; Lajemi, M.; Kimura, M.; Thomas, F.; Skurnick, J.; Labat, C.; Bean, K. \& Aviv, A. (2001). Telomere length as an indicator of biological ageing: the gender effect and relation with pulse pressure and pulse wave velocity. Hypertension, Vol.37, No.2, (February 2001), pp.381-385, ISSN 0194-911X

Benetos, A.; Gardner, J.P.; Zureik, M.; Labat, C.; Xiaobin, L.; Adamopoulos, C.; Temmar, M.; Bean, K.E.; Thomas, F.; Aviv, A. (2004). Short telomeres are associated with increased carotid atherosclerosis in hypertensive subjects. Hypertension, Vol.43, No.2, (February 2004), pp.182-185, ISSN 0194-911X

Bischoff, C.; Graakjaer, J.; Petersen, H.C.; Hjelmborg, J.B.; Vaupel, J.W.; Bohr, V.; Koelvraa, S. \& Christensen, K. (2005). The heritability of telomere length among the elderly and oldest-old. Twin Res Hum Genet, Vol.8, No.5, (october 2005), pp.433-439, ISSN 18324274

Blasco, M.A. (2007). The epigenetic regulation of mammalian telomeres. Nat Rev Genet, Vol.8, No.4, (April 2007), pp.299-309, ISSN 1471-0056

Brouilette, S.; Singh, R.K.; Thompson, J.R.; Goodall, A.H. \& Samani, N.J. (2003). White cell telomere length and risk of premature myocardial infarction. Arterioscler Thromb Vasc Biol, Vol.23, No.5, (May 2003), pp.842-846, ISSN 1079-5642

Brouilette, S.W.; Moore, J.S.; McMahon, A.D.; Thompson, J.R.; Ford, I.; Shepherd, J.; Packard, C.J.; Samani, N.J. \& West of Scotland Coronary Prevention Study Group. (2007). 
Telomere length, risk of coronary heart disease, and statin treatment in the West of Scotland Primary Prevention Study: a nested case-control study. Lancet, Vol.369, No.9556, pp.107-114, ISSN 0140-6736

Brambilla, D.J. \& McKinlay, S.M. (1989). A prospective study of factors affecting age at menopause. J Clin Epidemiol, Vol.42, No.11, (March 1989), pp.1031-1039, ISSN 08954356

Cargill, S.L; Carey, J.R; Muller, H.G. \& Anderson, G. (2003). Age of ovary determines remaining life expectancy in old ovariectomized mice. Aging Cell, Vol.2, No.3, (June 2003), pp.185-190, ISSN 1474-9718

Cattan, V.; Mercier, N.;, Gardner, J.P.; Regnault, V.; Labat, C.; Mäki-Jouppila, J.; Nzietchueng. R.; Benetos, A.; Kimura, M.; Aviv, A. \& Lacolley, P. (2008). Chronic oxidative stress induces a tissue-specific reduction in telomere length in CAST/Ei mice. Free Radical Biol Med, Vol.44, No.8, (April 2008), pp.1592-1598, ISSN 0891-5849

Cawthon, R.M.; Smith, K.R.; O'Brien, E.; Silvatchenko, A. \& Kerber, R.A. (2003). Association between telomere length in blood and mortality in people aged 60 years or older. Lancet, Vol.361, No.9355, (February 2003), pp.393-395, ISSN 0140-6736

Cherkas, L.F.; Aviv, A.; Valdes, A.M.; Hunkin, J.L.; Gardner, J.P.; Surdulescu, G.L.; Kimura, M. \& Spector, T.D. (2006). The effects of social status on biological ageing as measured by white-blood-cell telomere length. Aging Cell, Vol.5, No.5, (October 2006), pp.361-365, ISSN 1474-9718

Chin, L.; Artandi, S.E.; Shen Q.; Tam, A.; Lee, S.L.; Gottlieb, G.J.; Greider, C.W. \& DePinho R.A. (1999). p53 deficiency rescues the adverse effects of telomere loss and cooperates with telomere dysfunction to accelerate carcinogenesis. Cell, Vol.97, No.4, (May 1999), pp.527-538, ISSN 0092-8674

Cocuzza, M.; Athayde, K.S.; Agarwal, A.; Sharma, R.; Pagani, R.; Lucon, A.M.; Srougi, M. \& Hallak, J. (2008). Age-related increase of reactive oxygen species in neat semen in healthy fertile men. Urology, Vol.71, No.3, (March 2008), pp.490-494, ISSN 0090-4295

Cramer, D.W.; Xu, H. \& Harlow, B.L. (1995). Family history as a predictor of early menopause. Fertil Steril, Vol.64, No.4, (October 1995), pp.740-745, ISSN 0015-0282

Crow, J.F. (2000). The origins, patterns and implications of human spontaneous mutations. Nat Rev Genet, Vol.1, No.1, (October 2000), pp.40-47, ISSN 1471-0056

De Boeck, G.; Forsyth, R.G.; Praet, M. \& Hogendoorn, P.C. (2009). Telomere-associated proteins: cross-talk between telomere maintenance and telomere-lengthening mechanisms. J Pathol, Vol.217, No.3, (February 2009), pp.327-344, ISSN 0022-3417

de Lange, T. (2005). Shelterin: the protein complex that shapes and safeguards human telomeres. Genes Dev, Vol.19, No.18, (September 2005), pp.2100-2110, ISSN 08909369

De Meyer, T.; Rietzschel, E.R.; De Buyzere, M.L.; De Bacquer, D.; Van Criekinge, W.; De Backer, G.G.; Gillebert, T.C.; Van Oostveldt, P.; Bekaert, S. \& Asklepios investigators. (2007). Paternal age at birth is an important determinant of offspring telomere length. Hum Mol Genet, Vol.16, No.24, (December 2007), pp.3097-3102, ISSN 0964-6906

Demissie, S.; Levy, D.; Benjamin, E.J.; Cupples, L.A.; Gardner, J.P.; Herbert, A.; Kimura, M.; Larson, M.G.; Meigs, J.B.; Keaney, J.F. \& Aviv, A. (2006). Insulin resistance, oxidative stress, hypertension, and leukocyte telomere length in men from the 
Framingham Heart Study. Aging Cell, Vol.5, No.4, (August 2006), pp.325-330, ISSN 1474-9718

Desai, N.; Sabanegh, E. Jr.; Kim, T. \& Agarwal, A. (2010). Free radical theory of aging: implications in male infertility. Urology, Vol.75, No.1, (January 2010), pp.14-19, ISSN 0090-4295

Dorland, M.; Van Kooij, R.J. \& te Velde, E.R. (1998). General ageing and ovarian ageing. Maturitas, Vol.30, No.2, (October 1998), pp.113-118, ISSN 0378-5122

Dumollard, R.; Duchen, M. \& Carroll, J. (2007). The role of mitochondrial function in the oocyte and embryo. Curr Top Dev Biol, Vol.77, pp.21-49, ISSN 0070-2153

Duncan, F.E.; Chiang, T.; Schultz, R.M. \& Lampson, M.A. (2009). Evidence that a defective spindle assembly checkpoint is not the primary cause of maternal age-associated aneuploidy in mouse eggs. Biol Reprod, Vol.81, No.4, (October 2009), pp.768-776, ISSN 0006-3363

Dunson, D.B.; Baird, D.D. \& Colombo, B. (2004). Increased infertility with age in men and women. Obstet Gynecol, Vol.103, No.1, (January 2004), pp.51-56, ISSN 0029-7844

Epel, E.S.; Blackburn, E.H.; Lin, J.; Dhabhar, F.S.; Adler, N.E.; Morrow, J.D. \& Cawthon, RM. (2004). Accelerated telomere shortening in response to life stress. Proc Natl Acad Sci U S A, Vol.101, No.49, (December 2004), pp.17312-17315, ISSN 0027-8424

Faddy, M.J.; Gosden, R.G.; Gougeon, A.; Richardson, S.J. \& Nelson, J.F. (1992). Accelerated disappearance of ovarian follicles in mid-life: implications for forecasting menopause. Hum Reprod, Vol.7, No.10, (November 1992), pp.1342-1346, ISSN 02681161

Faddy, M.J. (2000). Follicle dynamics during ovarian ageing. Mol Cell Endocrinol, Vol.163, No1-2, (May 2000), pp.43-48, ISSN 0303-7207

Ferreira, R.C.; Braga, D.P.; Bonetti, T.C.; Pasqualotto, F.F.; Iaconelli, A. Jr. \& Borges, E. Jr. (2010). Negative influence of paternal age on clinical intracytoplasmic sperm injection cycle outcomes in oligozoospermic patients. Fertil Steril, Vol.93, No.6, (April 2010), pp.1870-1874, ISSN 0015-0282

Fisch, H.; Hyun, G.; Golden, R.; Hensle, T.W.; Olsson, C.A. \& Liberson, G.L. (2003). The influence of paternal age on Down syndrome. J Urol, Vol.169, No.6, (June 2003), pp.2275-2278, ISSN 0022-5347

Fitzpatrick, A.L.; Kronmal, R.A.; Gardner, J.P.; Psaty, B.M.; Jenny, N.S.; Tracy, R.P.; Walston, J.; Kimura, M. \& Aviv, A. (2007). Leukocyte telomere length and cardiovascular disease in the cardiovascular health study. Am J Epidemiol, Vol.165, No.1, (January 2007), pp.14-21, ISSN 0002-9262

Furumoto, K.; Inoue, E.; Nagao, N.; Hiyama, E. \& Miwa, N. (1998). Age-dependent telomere shortening is slowed down by enrichment of intracellular vitamin $\mathrm{C}$ via suppression of oxidative stress. Life Sci, Vol.63, No.11, (August 1998), pp.935-948, ISSN 0024-3205

Garcia-Cruz, R.; Brieno, M.A.; Roig, I.; Grossmann, M.; Velilla, E.; Pujol, A.; Cabero, L.; Pessarrodona, A.; Barbero, J.L.; Garcia Caldes, M. (2010). Dynamics of cohesin proteins REC8, STAG3, SMC1 beta and SMC3 are consistent with a role in sister chromatid cohesion during meiosis in human oocytes. Hum Reprod, Vol.25, No.9, (September 2010), pp.2316-2327, 0268-1161 
Gardner, J.P.; Li, S.; Srinivasan, S.R.; Chen, W.; Kimura, M.; Lu, X.; Berenson, G.S. \& Aviv, A. (2005). Rise in insulin resistance is associated with escalated telomere attrition. Circulation, Vol.111, No.17, (May 2005), pp.2171-2177, ISSN 0009-7322

Gavrilov, L. A. \& Gavrilova, N. S. (2003). The quest for a general theory of aging and longevity. Sci Aging Knowledge Environ, Vol.28, (July 2003), RE5, ISSN 1539-6150

Gilson, E. \& Géli, V. (2007). How telomeres are replicated. Nat Rev Mol Cell Biol, Vol.8, No.10, (October 2007), pp.825-838, ISSN 1471-0072

Ginsburg, J. (1991). What determines the age at the menopause? The number of ovarian follicles seems the most important factor. BrMedJ Vol.302, No.6788, (June 2001), pp.1288-1289, ISSN 09598138. ISBN 09598138

Glaser, R.L. \& Jabs, E.W. (2004) Dear old dad. Sci Aging Knowledge Environ, Vol.21, No.3, (January 2004), pp.re1, ISSN 1539-6150

Gonzalo, S.; Jaco, I.; Fraga, M.F.; Chen, T.; Li, E.; Etseller, M. \& Blasco, M.A. (2006). DNA methyltransferases control telomere length and telomere recombination in mammalian cells. Nat Cell Biol, Vol.8, No.4, (April 2006), pp. 416-424, ISSN 14657392

Greer, E.L. \& Brunet, A. (2008). Signaling networks in aging. J Cell Sci, Vol.121, No.4, (February 2008), pp.407-412, ISSN 0021-9533

Greider, C.W. \& Blackburn, E.H. (1985). Identification of a specific telomere terminal transferase activity in Tetrahymena extracts. Cell, Vol.43, No.2, (December 1985), pp.405-413, ISSN 0092-8674

Hamatani, T.; Falco, G.; Carter, M.G.; Akutsu, H.; Stagg, C.A.; Sharov, A.A.; Dudekula, D.B.; VanBuren, V. \& Ko, M.S. (2004). Ageassociated alteration of gene expression patterns in mouse oocytes. Hum Mol Genet, Vol.13, No.19, (October 2004), pp.22632278, ISSN 0964-6906

Hanna, C.W.; Bretherick, K.L.; Gair, J.L.; Fluker, M.R.; Stephenson, M.D. \& Robinson, W.P. (2009). Telomere length and reproductive aging. Hum Reprod, Vol.24, No.5, (May 2009), pp.1206-11, ISSN 0268-1161

Harman, D. (1956). Aging: a theory based on free radical and radiation chemistry. J Gerontol, Vol.11, No.3, (July 1956), pp.298-300, ISSN 0022-1422

Harman, D. (1972). The biologic clock: the mitochondria? J Am Geriatr Soc, Vol.20, No.4, (April 1972), pp.145-147, ISSN 0002-8614

Harvey, A.J; Gibson, T.C.; Quebedeaux, T.M. \& Brenner, C.A. (2007). Impact of assisted reproductive technologies: a mitochondrial perspective of cytoplasmic transplantation. Curr Top Dev Biol, Vol.77, pp.229-249, ISSN 0070-2153

Hassold, T. \& Chiu, D. (1985). Maternal age-specific rates of numerical chromosome abnormalities with special reference to trisomy. Hum Genet, Vol.70, No.1, pp.11-17, ISSN 0340-6717

Hassold, T.; Jacobs, P.A.; Leppert, M. \& Sheldon, M. (1987). Cytogenetic and molecular studies of trisomy 13. J Med Genet, Vol.24, No.2, (December 1987), pp.725-732, ISSN 0022-2593

Hassold, T.J.; Pettay, D.; Freeman, S.B.; Grantham, M. \& Takaesu, N. (1991). Molecular studies of nondisjunction in trisomy 16. J Med Genet, Vol.28, No.3, (March 1991), pp.159-162, ISSN 0022-2593 
Hassold, T. \& Hunt, P. (2001). To err (meiotically) is human: the genesis of human aneuploidy. Nat Rev Genet, Vol.2, No.4, (April 2001), pp.280-291, ISSN 14710056. ISBN 1471-0056

Hastie, N.D; Dempster, M.; Dunlop, M.G.; Thompson, A.M.; Green, D.K. \& Allshire, R.C. (1990). Telomere reduction in human colorectal carcinoma and with ageing. Nature, Vol.346, No.6287, (August 1990), pp.866-868, ISSN 0028-0836

Hayflick, L. \& Moorhead, P.S. (1961). The serial cultivation of human diploid cell strains. Exp Cell Res, Vol.25, (December 1961), pp.585-621, ISSN 0014-4827

Henderson, S.A. \& Edwards, R.G. (1968). Chiasma frequency and maternal age in mammals. Nature, Vol.218, No.5136, (April 1968), pp.22-28, ISSN 0028-0836

Henle, E.S.; Han, Z.; Tang, N.; Rai, P.; Luo, Y. \& Linn, S. (1999). Sequence-specific DNA cleavage by $\mathrm{Fe} 2+-$ mediated Fenton reactions has possible biological implications. $J$ Biol Chem, Vol.274, No.2, (January 1999), pp.962-971, ISSN 0021-9258

Herrera, E.; Samper, E.; Martín-Caballero, J.; Flores, J.M.; Lee, H.W \&, Blasco, M.A. (1999). Disease states associated with telomerase deficiency appear earlier in mice with short telomeres. EMBO J, Vol.18, No.11, (June 1999), pp.2950-2960, ISSN 0261-4189

Hodges, C.A.; Revenkova, E.; Jessberger, R.; Hassold, T.J. \& Hunt, P.A. (2005). SMC1betadeficient female mice provide evidence that cohesins are a missing link in agerelated nondisjunction. Nat Genet. Vol.37, No.12, December 2005), pp.1351-1355, ISSN 1061-4036

Honda, S.; Hjelmeland, L.M. \& Handa, J.T. (2001a). Oxidative stress-induced single strand breaks in chromosomal telomeres of human retinal pigment epithelial cells in vitro. Invest Ophthalmol Vis Sci, Vol.42, No.9, (August 2001), pp.2139-2144, ISSN 01460404

Honda, S.; Weigel, A.; Hjelmeland, L.M. \& Handa, J.T. (2001b). Induction of telomere shortening and replicative senescence by cryopreservation. Biochem Biophys Res Commun, Vol.282, No.2, (March 2001), pp.493-498, ISSN 0006-291X

Houben, J.M.; Moonen, H.J.; van Schooten, F.J. \& Hageman G.J. (2008). Telomere length assessment: biomarker of chronic oxidative stress? Free Radic Biol Med, Vol.44, No.3, (February 2008), pp.235-246, ISSN 0891-5849

Hsin, H. \& Kenyon, C. Signals from the reproductive system regulate the lifespan of C. elegans. Nature, Vol.399, No.6734, (May 1999), pp.362-366, ISSN 0028-0836

Hunt, P.; LeMaire, R.; Embury, P.; Sheean, L. \& Mroz, K. (2007). Analysis of chromosome behavior in intact mammalian oocytes: monitoring the segregation of a univalent chromosome during female meiosis. Hum Mol Genet, Vol.4, No.11, (November 1995), pp.2007-2012, ISSN 0964-6906

Hunt, P.A. \& Hassold, T.J. (2008). Human female meiosis: What makes a good egg go bad? Trends Genet, Vol.24, No.2, (February 2008), pp.86-93, ISSN 0168-9525

Jeanclos, E.; Schork, N.J.; Kyvik, K.O.; Kimura, M.; Skurnick, J.H. \& Aviv, A. (2000). Telomere length inversely correlates with pulse pressure and is highly familial. Hypertension, Vol.36, No.2, (August 2000), pp.195-200, ISSN 0194-911X

Johnson, J.; Canning, J.; Kaneko, T.; Pru, J.K. \& Tilly, J.L. (2004). Germline stem cells and follicular renewal in the postnatal mammalian ovary. Nature, Vol.428, No.6979, (March 2004), pp.145-150, ISSN 0028-0836 
Kato, I.; Toniolo, P.; Akhmedkhanov, A.; Koenig, K.L.; Shore, R. \& Zeleniuch-Jacquotte, A. (1998). Prospective study of factors influencing the onset of natural menopause. $J$ Clin Epidemiol, Vol.51, No.12, (December 1998), pp.1271- 1276, ISSN 0895-4356

Keefe, D. L.; Franco, S.; Liu, L.; Cho, B.; Weitzen, S. \& Blasco, M.A. (2004). Telomere length and reproductive outcome in women. Am J Obstet Gynecol, Vol.192, No.4, (April 2005), pp.1256-1260, ISSN 0002-9378

Keefe, D.L; Marquard, K. \& Liu, L. (2006). The telomere theory of reproductive senescence in women. Curr Opin Obstet Gynecol, Vol.18, No.3, (June 2006), pp.280-285, ISSN 1040$872 X$

Keefe, D.L.; Liu, L. \& Marquard, K. (2007). Telomeres and aging-related meiotic dysfunction in women. Cell Mol Life Sci, Vol.64, No.2, (January 2007), pp.139-143, ISSN 1420$682 X$

Keefe, D.L. \& Liu, L. (2009). Telomeres and reproductive aging. Reprod Fertil Dev, Vol.21, No.1, pp.10-14, ISSN 1031-3613

Kline, K.; Kinney, A.; Levin, B. \& Warburton, D. (2000). Trisomic pregnancy and early age at menopause. Am J Hum Genet, Vol.67, No.2, (August 2000), pp.395-404, ISSN 00029297

Kruk, P.A.; Rampino, N.J. \& Bohr, V.A. (1995). DNA damage and repair in telomeres: relation to aging. Proc Natl Acad Sci USA, Vol.92, No.1, (January 1995), pp.258-262, ISSN 0027-8424

Kuhnert, B. \& Nieschlag, E. (2004). Reproductive functions of the ageing male. Hum Reprod Update, Vol.10, No.4, (July-August 2004), pp.327-339, ISSN 1355-4786

Lansdorp, P.M. (2005). Major cutbacks at chromosome ends. Trends Biochem Sci, Vol.30, No.7, (July 2005), pp.388-395, ISSN 0968-0004

Lee, H.W.; Blasco, M.A.; Gottlieb, G.J.; Horner, J.W. 2nd, Greider, C.W. \& DePinho, R.A. (1998). Essential role of mouse telomerase in highly proliferative organs. Nature, Vol.392, No.6676, (April 1998), pp.569-74, ISSN 0028-0836

LeMaire-Adkins, R.; Radke, K. \& Hunt, P. A. (1997) Lack of checkpoint control at the metaphase/anaphase transition: a mechanism of meiotic nondisjunction in mammalian females. J Cell Biol, Vol.139, No.7, (December 1997), pp. 1611-1619, ISSN 0021-9525

Liu, L.; Trimarchi, J.R.; Smith, P.J. \& Keefe, D.L. (2002a). Mitochondrial dysfunction leads to telomere attrition and genomic instability. Aging Cell, Vol.1, No.1, (October 2002), pp.40-46, ISSN 1474-9718

Liu, L.; Blasco, M. \& Kefe, D.L. (2002b) Requirement of functional telomeres for metaphase chromosome alignments and integrity of meiotic spindles. EMBO Rep, Vol.3, No.3, (March 2002), pp.230-234, ISSN 1469-221X

Liu L, Trimarchi JR, Navarro P, Blasco MA, Keefe DL. (2003). Oxidative stress contributes to arsenic-induced telomere attrition, chromosome instability, and apoptosis. J Biol Chem, Vol. 278, No.34, (May 2003), pp.1998-2004, ISSN 0021-9258

Liu, L.; Franco, S.; Spyropoulos, B.; Moens, P.B.; Blasco, M.A. \& Kefe, D.L. (2004). Irregular telomeres impair meiotic synapsis and recombination in mice. Proc Natl Acad Sci USA, Vol.101, No.17, (April 2004), pp.6496-6501, ISSN 0027-8424

Liu, Y.;Wu, C.; Lyu, Q. \& Yang, D. (2007). Albertini DF, Keefe DL, Liu L. Germline stem cells and neo-oogenesis in the adult human ovary. Dev Biol, Vol.306, No.1, (June 2007), pp.112-120, ISSN 0012-1606 
Liu, L. \& Keefe, D.L. (2008). Defective cohesin is associated with age-dependent misaligned chromosomes in oocytes. Reprod Biomed Online, Vol.16, No.1, (January 2008), pp.103-112, ISSN 1472-6483

Malter, H.E. \& Cohen, J. (2002). Ooplasmic transfer: animal models assist human studies. Reprod Biomed Online, Vol.5, No.1, (July-August 2002), pp.26-35, ISSN 14726483

Martin, R.H. \& Rademaker, A.W. (1987) The effect of age on the frequency of sperm chromosomal abnormalities in normal men. Am J Hum Genet, Vol.41, No.3, (September 1987), pp.484-492, ISSN 0002-9297

Matthews, T.J. \& Hamilton, B.E. (2009). Delayed childbearing: More women are having their first child later in life. NCHS Data Brief, Vol.21, (August 2009), pp.1-8, ISSN 19414935

May, K.M.; Jacobs, P.A.; Lee, M.; Ratcliffe, S.; Robinson, A.; Nielsen, J. \& Hassold, T.J. (1990). The parental origin of the extra X chromosome in 47,XXX females. Am J Hum Genet, Vol.46, No.4, (April 1990), pp.754-761, ISSN 0002-9297

Mayer, S.; Bruderlein, S.; Perner, S.; Waibel, I.; Holdenried, A.; Ciloglu, N.; Hasel, C.; Mattfeldt, T.; Nielsen, K.V. \& Möller, P. (2006) Sex-specific telomere length profiles and age-dependent erosion dynamics of individual chromosome arms in humans. Cytogenet Genome Res, Vol.112, No.3-4, (July 2005), pp.194-201, ISSN 1424-8581

Muller, H.J. (1938) The remaking of chromosomes. Collecting Net 13:15

Murnane, J.P. \& Sabatier, L. (2004). Chromosome rearrangements resulting from telomere dysfunction and their role in cancer. Bioessays, Vol.26, No.11, (November 2004), pp.1164-1174, ISSN 0265-9247

Nawrot, T.S.; Staessen, J.A.; Gardner, J.P. \& Aviv, A. (2004). Telomere length and possible link to X chromosome. Lancet, Vol.363, No.9408, (February 2004), pp.507-510, ISSN 0140-6736

Nicolaides, K.H.; Spencer, K.; Avgidou, K.; Faiola, S. \& Falcon, O. (2005). Multicenter study of first-trimester screening for trisomy 21 in 75821 pregnancies: results and estimation of the potential impact of individual risk-orientated two-stage firsttrimester screening. Ultrasound Obstet Gynecol, Vol.25, No.3, (March 2005), pp.221226, ISSN 0960-7692

Nittis, T., Guittat, L. \& Stewart, S.A. (2008). Alternative lengthening of telomeres (ALT) and chromatin: is there a connection? Biochimie, Vol.90, No.1, (January 2008), pp.5-12, ISSN 0300-9084

Oikawa, S.; Tada-Oikawa, S. \& Kawanishi, S. (2001). Site-specific DNA damage at the GGG sequence by UVA involves acceleration of telomere shortening. Biochemistry, Vol.40, No.15, (April 2001), pp.4763-4768, ISSN 0006-2960

Ottolenghi, C.; Uda, M.; Hamatani, T.; Crisponi, L.; Garcia, J.E.; Ko, M.; Pilia, G.; Sforza, C.; Schlessinger, D. \& Forabosco, A. (2004). Aging of oocyte, ovary, and human reproduction. Ann N Y Acad Sci, Vol.1034, (December 2004), pp.117-131, ISSN 00778923

Palm, W.\& de Lange, T. (2008). How shelterin protects mammalian telomeres. Annu Rev Genet, Vol.42, (December 2008), pp.301-334, ISSN 0066-4197

Pan, H.; Ma, P.; Zhu, W. \& Schultz, R.M. (2008). Age-associated increase in aneuploidy and changes in gene expression in mouse eggs. Dev Biol, Vol.316, No.2, (April 2008), pp.397-407, ISSN 0012-1606 
Pan, M.H.; Lai, C.S.; Tsai, M.L.; Wu, J.C. \& Ho, C.T. (2011). Molecular mechanisms for antiaging by natural dietary compounds. Mol Nutr Food Res, Vol.(November 2011), doi: 10.1002/mnfr.201100509. [Epub ahead of print] ISSN 1613-4125

Panossian, L.A.; Porter, V.R.; Valenzuela, H.F.; Zhu, X.; Reback, E.; Masterman, D.; Cummings, J.L. \& Effros, R.B. (2003). Telomere shortening in T cells correlate with Alzheimer's disease status. Neurobiol Aging, Vol.24, No.1, (January-February 2003), pp.77-84, ISSN 0197-4580

Passos, J. F., \& von Zglinicki, T. (2005). Mitochondria, telomeres and cell senescence. Exp Geronto, Vol.40, No.6, (June 2005), pp.466-472, ISSN 0531-5565

Passos, J.F.; Saretzki, G. \& von Zglinicki, T. (2007). DNA damage in telomeres and mitochondria during cellular senescence: is there a connection? Nucleic Acids Res, Vol.35, No.22, pp.7505-7513, ISSN 0305-1048

Petersen, S.; Saretzki, G. \& von Zglinicki, T. (1998). Preferential accumulation of singlestranded regions in telomeres of human fibroblasts. Exp Cell Res, Vol.239, No.1, (February 1998), pp.152-160, ISSN 0014-4827

Perls, T.T.; Alpert, L. \& Fretts, R.C. (1997). Middle-aged mothers live longer. Nature Vol.389, No.6647, (September 1997), pp.133, ISSN 0028-0836

Perls T, Levenson R, Regan M, Puca A. (2002). What does it take to live to 100? Mech Ageing Dev, Vol.123, No.2-3, (January 2002), pp.231-242, ISSN 0047-6374

Perls, T.T. \& Fretts, R.C. (2001). The evolution of menopause and human life span. Ann Hum Biol, Vol.28, No.3, (May-June 2001), pp.237-245, ISSN 0301-4460

Petersen, S.; Saretzki, G. \& von Zglinicki, T. (1998). Preferential accumulation of singlestranded regions in telomeres of human fibroblasts. Exp Cell Res, Vol.239, No.1, (February 1998), pp.152-160, ISSN 0014-4827

Pines, A.; Shapira, I.; Mijatovic, V.; Margalioth, E.J. \& Frenkel, Y. (2002). The impact of hormonal therapy for infertility on age at menopause. Maturitas, Vol.41, No.4, (April 2002), pp.283-287, ISSN 0378-5122

Plastira, K.; Msaouel, P.; Angelopoulou, R.; Zanioti, K.; Plastiras, A.; Pothos, A.; Bolaris, S.; Paparisteidis, N. \& Mantas, D. (2007). The effects of age on DNA fragmentation, chromatin packaging and conventional semen parameters in spermatozoa of oligoasthenoteratozoospermic patients. J Assist Reprod Genet, Vol.24, No.10, (October 2007), pp.437-443, ISSN 1058-0468

Prieto, I.; Tease, C.; Pezzi, N.; Buesa, J.M,.; Ortega, S.; Kremer, L.; Martinez, A.; Martinez, A.C.; Hulten, M.A. \& Barbero, J.L. (2004). Cohesin component dynamics during meiotic prophase I in mammalian oocytes. Chromosome Res, Vol.12, No.3, pp.197213, ISSN 0967-3849

Revenkova, E. \& Jessberger, R. (2005). Keeping sister chromatids together: cohesins in meiosis. Reproduction, Vol.130, No.6, (December 2005), pp.783-790, ISSN 1470-1626

Revenkova, E.; Herrmann, K; Adelfalk, C. \& Jessberger, R. (2010). Oocyte cohesin expression restricted to predictyate stages provides full fertility and prevents aneuploidy. Curr Biol, Vol.20, No.17, (September 2010), pp.1529-1533, ISSN 0960-9822

Richter, T. \& von Zglinicki, T. (2007). A continuous correlation between oxidative stress and telomere shortening in fibroblasts. Exp Gerontol, Vol.42, No.11, (November 2007), pp.1039-1042, ISSN 0531-5565

Roeder, G.S. (1997). Meiotic chromosomes:it takes two to tango. Genes Dev, Vol.11, No.20, (October 1997), pp.2600-2621, ISSN 0890-9369 
Roig, I.; Liebe, B.; Egozcue, J.; Cabero, L.; Garcia, M. \& Scherthan, H. (2004). Female-specific features of recombinatorial double-stranded DNA repair in relation to synapsis and telomere dynamics in human oocytes. Chromosoma, Vol.113, No.1, (August 2004), pp.22-23, ISSN 0009-5915

Rufer, N.; Brummendorf, T.H.; Kolvraa, S.; Bischoff, C.; Christensen, K.; Wadsworth, L.; Schulzer, M. \& Lansdorp, P.M. (1999). Telomere fluorescence measurements in granulocytes and $\mathrm{T}$ lymphocyte subsets point to a high turnover of hematopoietic stem cells and memory T cells in early childhood. J Exp Med, Vol.190, No.2, (July 1999), pp.157-167, ISSN 0022-1007

Saretzki, G.; Sitte, N.; Merkel, U.; Wurm, R.E. \& von Zglinicki, T. (1999). Telomere shortening triggers a p53-dependent cell cycle arrest via accumulation of G-rich single stranded DNA fragments. Oncogene, Vol.18, No.37, (September 1999), pp.5148-5158, ISSN 0950-9232

Sartorelli, E.M.P.; Mazuccatto, L.F \& de Pina-Neto J.M. (2001). Effect of paternal age on human sperm chromosomes. Fertil Steril, Vol.76, No.6, (December 2001), pp.11191123, ISSN 0015-0282

Sauer, M.V. (1998). The impact of age on reproductive potential: lessons learned from oocyte donation. Maturitas, Vol. 30, No.2, (October 1998), pp.221-225, ISSN 0378-5122

Scherthan, H.; Weich, S.; Schwegler, H.; Heyting, C.; Harle, M. \& Cremer, T. (1996). Centromere and telomere movements during early meiotic prophase of mouse and man are associated with the onset of chromosome pairing. J. Cell Biol, Vol.134, No.5, (September 1996), pp.1109-1125, ISSN 0021-9525

Scherthan, H. (2006). Factors directing telomere dynamics in synaptic meiosis. Biochem Soc Trans, Vol.34, No.4, (August 2006), pp.550-553, ISSN 0300-5127

Serra, V.; von Zglinicki, T.; Lorenz, M. \& Saretzki, G. (2003). Extracellular superoxide dismutase is a major antioxidant in human fibroblasts and slows telomere shortening. J Biol Chem, Vol.278, No.9, (February 2003), pp.6824-6830, ISSN 00219258

Shay, J.W. \& Wright, W.E. (2000). Hayflick, his limit, and cellular ageing. Nat Rev Mol Cell Biol, Vol.1, No.1, (October, 2000), pp.72-76, ISSN:1471-0072.

Shay, J.W. \& Wright, W.E. (2007). Hallmarks of telomeres in ageing research. J Pathol, Vol.211, No.2, (January 2007), pp. 114-123, ISSN 0022-3417

Sitte, N.; Saretzki, G. \& von Zglinicki, T. (1998). Accelerated telomere shortening in fibroblasts after extended periods of confluency. Free Radic Biol Med, Vol.24, No.6, (April 1998), pp.885-893, ISSN 0891-5849

Slagboom, P.E.; Droog, S. \& Boomsma, D.I. (1994). Genetic determination of telomere size in humans: a twin study of three age groups. Am J Hum Genet, Vol.55, No.5, (November 1994), pp.876-882, ISSN 0002-9297

Snieder, H.; MacGregor, A.J. \& Spector, T.D. (1998). Genes control the cessation of a woman's reproductive life: a twin study of hysterectomy and age at menopause. $J$ Clin Endocrinol Metab, Vol.83, No.6, (June 1998), pp.1875-1880, ISSN 0021-972X

Steuerwald, N.M; Bermudez, M.G.; Wells, D.; Munne, S. \& Cohen, J. Maternal age-related differential global expression profiles observed in human oocytes. Reprod Biomed Online, Vol.14, No.6, (June 2007), pp.700-708, ISSN 14726483

Stewart, A.F. \& Kim, E.D. (2011). Fertility Concerns for the Aging Male. Urology, Vol.78, No.3, (September 2011), pp.496-499, ISSN 0090-4295 
Stolwijk, A.M.; Zielhuis, G.A.; Sauer, M.V.; Hamilton, C.J. \& Paulson, R.J. (1997). The impact of the woman's age on the success of standard and donor in vitro fertilization. Fertil Steril, Vol.67, No.4, (April 1997), pp.702-710, ISSN 0015-0282

Takaesu, N.; Jacobs, P.A.; Cockwell, A.; Blackston, R.D.; Freeman, S.; Nuccio, J.; Kurnit, D.M.; Uchida, I.; Freeman, V. \& Hassold, T. Nondisjunction of chromosome 21. (1990). Am J Med Genet Suppl, Vol.7, pp.175-181, ISSN 1040-3787

Takeuchi, T.; Neri, Q.V.; Katagiri, Y.; Rosenwaks, Z. \& Palermo, G.D. (2005). Effect of treating induced mitochondrial damage on embryonic development and epigenesis. Biol Reprod, Vol.72, No.3, (March 2005), pp.584-592, ISSN 0006-3363

Takai, H.; Smogorzewska, A. \& de Lange, T. (2003). DNA damage foci at dysfunctional telomeres. Curr Biol, Vol.13, No.17, (September 2003), pp.1549-1556, ISSN 0960-9822

Tarin, J.J. (1995). Aetiology of age-associated aneuploidy: a mechanism based on the 'free radical theory of ageing'. Hum Reprod, Vol.10, No.6, (June 1995), pp.1563-1565, ISSN 0268-1161

Tarin, J.J.; Brines, J. \& Cano, A. (1998). Long-term effects of delayed parenthood. Hum Reprod, Vol.13, No.9, (September 1998), pp.2371-2376, ISSN 0268-1161

Tarin, J.J.; Gomez-Piquer, V.; Pertusa, J.F.; Hermenegildo, C. \& Cano, A. (2004). Association of female aging with decreased parthenogenetic activation, raised MPF, and MAPKs activities and reduced levels of glutathione S-transferases activity and thiols in mouse oocytes. Mol Reprod Dev, Vol.69, No.4, (December 2004), pp.402410, ISSN 1040-452X

Tarín, J.J.; Pérez-Albalá, S. \& Cano, A. (2001). Cellular and morphological traits of oocytes retrieved from aging mice after exogenous ovarian stimulation. Biol Reprod, Vol.65, No.1, (July 2001), pp.141-150, ISSN 0006-3363

Terry, D.F.; Nolan, V.G.; Andersen, S.L.; Perls, T.T. \& Cawthon, R. (2008). Association of longer telomeres with better health in centenarians. J Gerontol A Biol Sci Med Sci, Vol.63, No.8, (August 2008), pp.809-812, ISSN 1079-5006

te Velde ER, Pearson PL. The variability of female reproductive ageing. (2002). Hum Reprod Update, Vol.8, No.2, (March-April 2002), pp.141-154, ISSN 1355-4786

Thouas, G.A.; Trounson, A.O. \& Jones, G.M. (2005). Effect of female age on mouse oocyte developmental competence following mitochondrial injury. Biol Reprod, Vol.73, No.2, (August 2005), pp.366-373, ISSN 0006-3363

Toner, J.P.; Philput, C.B.; Jones, G.S. \& Muasher, S.J. (1991). Basal follicle-stimulating hormone level is a better predictor of in vitro fertilization performance than age. Fertil Steril, Vol.55, No.4, (April 1991), pp.784-791, ISSN 0015-0282

Torgerson, D.J.; Thomas, R.E. \& Reid, D.M. (1997). Mothers and daughters menopausal ages: is there a link? Eur J Obstet Gynecol Reprod Biol, Vol.74, No.1, (July 1997), pp.63-66, ISSN 0301-2115

Unryn, B.M.; Cook, L.S. \& Riabowol, K.T. (2005). Paternal age is positively linked to telomere length of children. Aging Cell, Vol.4, No.2, (April 2005), pp.97-101, ISSN 1474-9718

Vagnini, L.; Baruffi, R.L.; Mauri, A.L.; Petersen, C.G.; Massaro, F.C.; Pontes, A.; Oliveira, J.B. \& Franco, J.G. Jr. (2007). The effects of male age on sperm DNA damage in an infertile population. Reprod Biomed Online, Vol.15, No.5, (November 2007), pp.514519, ISSN 1472-6483 
Valdes, A.M.; Andrew, T.; Gardner, J.P.; Kimura, M.; Oelsner, E.; Cherkas, L.F.; Aviv, A. \& Spector, T.D. (2005) Obesity, cigarette smoking, and telomere length in women. Lancet, Vol.366, No.9486, (August 2005), pp.662-664, ISSN 0140-6736

Van Blerkom, J. (2000). Intrafollicular influences on human oocyte developmental competence: perifollicular vascularity, oocyte metabolism and mitochondrial function. Hum Reprod, Vol.15, No.Suppl 2, (July 2000), pp.173-188, ISSN 02681161

Vasa-Nicotera, M.; Brouilette, S.; Mangino, M.; Thompson, J.R.; Braund, P.; Clemitson, J.R.; Mason, A.; Bodycote, C.L.; Raleigh, S.M.; Louis, E. \& Samani, N.J. (2005) Mapping of a major locus that determines telomere length in humans. Am J Hum Genet, Vol.76, No.1, (January 2005), pp.147-151, ISSN 0002-9297

Ventura, S.J. (1989). Trends and variations in first births to older women, United States, 1970-86. Vital Health Stat 21, Vol.47, (June 1989), pp.1-27, ISSN 1057-7629

von Zglinicki, T.; Saretzki, G.; Döcke, W. \& Lotze, C. (1995). Mild hyperoxia shortens telomeres and inhibits proliferation of fibroblasts: a model for senescence? Exp Cell Res, Vol.220, No.1, (September 1995), pp.186-193, ISSN 0014-4827

von Zglinicki, T.; Pilger, R. \& Sitte, N. (2000). Accumulation of single-strand breaks is the major cause of telomere shortening in human fibroblasts. Free Radic Biol Med, Vol.28, No.1, (January 2000), pp.64-74, ISSN 0891-5849

Von Zglinicki, T. (2002). Oxidative stress shortens telomeres. TRENDS in Biochemical Sciences, Vol.27, No.7, ( July 2002), pp. 339-344, ISSN 0968-0004

von Zglinicki, T.; Serra, V.; Lorenz, M.; Saretzki, G.; Lenzen-Grossimlighaus, R.; Gessner, R.; Risch, A. \& Steinhagen-Thiessen, E. (2000). Short telomeres in patients with vascular dementia: an indicator of low antioxidative capacity and possible risk factors? Lab Invest, Vol.80, No.11, (November 2010), pp.1739-1747, ISSN 00236837

Wai, L.K. (2004). Telomeres, Telomerase, and Tumorigenesis: Telomeres, the ChromosomeEnd Protectors. MedGenMed, Vol.6, No.3, (July, 2004), pp.19, ISSN:1531-0132

Wallenfang, M.R.; Nayak, R. \& DiNardo, S. ( 2006). Dynamics of the male germline stem cell population during aging of Drosophila melanogaster. Aging Cell, Vol.5, No.4, (August 2006), pp.297-304, ISSN 1474-9718

Warburton, D.; Dallaire, L.; Thangavelu, M.; Ross, L.; Levin, B. \& Kline, J. (2004). Trisomy recurrence: a reconsideration based on North American data. Am J Hum Genet, Vol.75, No.3, (September 2004), pp.376-385, ISSN 0002-9297

Whelan, E.A.; Sandler, D.P.; McConnaughey, D.R. \& Weinberg C.R. (1990). Menstrual and reproductive characteristics and age at natural menopause. Am J Epidemiol, Vol.131, No.4, (April 1990), pp.625-632, ISSN 0002-9262

Wright, V.C.; Chang, J.; Jeng, G. \& Macaluso, M. (2006). Assisted reproductive technology surveillance - United States, 2003. MMWR Surveill Summ, Vol.55, No.4, (May, 2006), pp.1-22, ISSN 1546-0738

Wu, X.; Amos, C.I.; Zhu, Y.; Zhao, H.; Grossman, B.H.; Shay, J.W.; Luo, S.; Hong, W.K. \& Spitz, M.R. (2003). Telomere dysfunction: a potential cancer predisposition factor. J Natl Cancer Inst, Vol.95, No.6, (August 2003), pp.1211-1218, ISSN 0027-8874

Xu, D.; Neville, R. \& Finkel, T. (2000). Homocysteine accelerates endothelial cell senescence. FEBS Lett, Vol.470, No.1, (March 2000), pp.20-24, ISSN 0014-5793 
Zhou, B.O.; Wang, S.S.; Zhang, Y.; Fu, X.H.; Dang, W.; Lenzmeier, B.A. \& Zhou, J.Q. (2011). Histone $\mathrm{H} 4$ lysine 12 acetylation regulates telomeric heterochromatin plasticity in Saccharomyces cerevisiae. PloS Genet, Vol.7, No.1, (January 2011), pp.1-8, ISSN 1553-7390 
(C) 2012 The Author(s). Licensee IntechOpen. This is an open access article distributed under the terms of the Creative Commons Attribution 3.0 License, which permits unrestricted use, distribution, and reproduction in any medium, provided the original work is properly cited. 